\title{
Climate model uncertainty versus conceptual geological uncertainty in hydrological modeling
}

\author{
T. O. Sonnenborg ${ }^{1}$, D. Seifert ${ }^{2}$, and J. C. Refsgaard ${ }^{1}$ \\ ${ }^{1}$ Geological Survey of Denmark and Greenland (GEUS), Department of Hydrology, Øster Voldgade 10, \\ 1350 Copenhagen, Denmark \\ ${ }^{2}$ ALECTIA A/S, Water \& Environment, Teknikerbyen 34, 2830 Virum, Denmark \\ Correspondence to: T. O. Sonnenborg (tso@geus.dk)
}

Received: 7 April 2015 - Published in Hydrol. Earth Syst. Sci. Discuss.: 29 April 2015

Revised: 13 August 2015 - Accepted: 21 August 2015 - Published: 16 September 2015

\begin{abstract}
Projections of climate change impact are associated with a cascade of uncertainties including in $\mathrm{CO}_{2}$ emission scenarios, climate models, downscaling and impact models. The relative importance of the individual uncertainty sources is expected to depend on several factors including the quantity that is projected. In the present study the impacts of climate model uncertainty and geological model uncertainty on hydraulic head, stream flow, travel time and capture zones are evaluated. Six versions of a physically based and distributed hydrological model, each containing a unique interpretation of the geological structure of the model area, are forced by 11 climate model projections. Each projection of future climate is a result of a GCM-RCM model combination (from the ENSEMBLES project) forced by the same $\mathrm{CO}_{2}$ scenario (A1B). The changes from the reference period (1991-2010) to the future period (2081-2100) in projected hydrological variables are evaluated and the effects of geological model and climate model uncertainties are quantified. The results show that uncertainty propagation is context-dependent. While the geological conceptualization is the dominating uncertainty source for projection of travel time and capture zones, the uncertainty due to the climate models is more important for groundwater hydraulic heads and stream flow.
\end{abstract}

\section{Introduction}

Climate change will have major impacts on human societies and ecosystems (IPCC, 2007). Climate change adaptation is, however, impeded by the large uncertainties arising from climate projection uncertainties as well as the uncertainties related to hydrological modeling (Foley, 2010; Refsgaard et al., 2013). Uncertainties related to climate projections are often considerable (Déqué et al., 2007; Seaby et al., 2013; IPCC, 2013), and may be divided into internal variability, model uncertainty and scenario uncertainty. Several studies (e.g., Hawkins and Sutton, 2011; Kjellström et al., 2011) have shown that model uncertainty dominates for lead times exceeding a couple of decades, while uncertainties in greenhouse gas emissions will take over towards the end of the present century. Assessments of uncertainties in climate change impacts on water resources become complicated, because climate projection uncertainties should be propagated through hydrological models, where a range of additional uncertainty sources need to be considered. These sources include uncertainties in input data, parameter values and model structural uncertainties, i.e., conceptualization of the representation of vegetation, soils, geology, etc. and process descriptions (Refsgaard et al., 2007). In hydrological modeling of groundwater conditions, the conceptual geological uncertainty often turns out as the dominant source of uncertainty (Neumann, 2003; Bredehoeft, 2005; Refsgaard et al., 2012).

Because of the complexities and computational aspects involved, it is not feasible to explicitly consider all sources of uncertainty in a single study. It is therefore interesting to know in which contexts the different sources of uncertainties will be dominating. Several studies have assessed the uncertainty propagation from climate projections through hydrological modeling (Minville et al., 2008; Bastola et al., 2011; Poulin et al., 2011; Dobler et al., 2012), concluding that in some cases climate model uncertainty dominates over hy- 


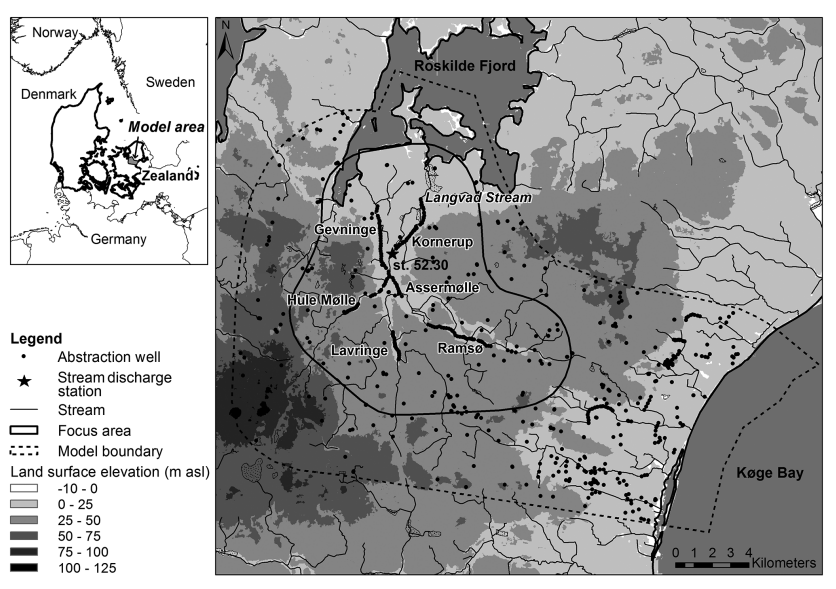

Figure 1. Model area of the Langvad Stream catchment area with land surface elevation, streams, abstraction wells and location of the main well fields in the focus area (the clusters of wells along the streams).

drological model uncertainty and vice versa in other cases. These studies have focussed on surface water hydrological systems, while we are not aware of studies that have investigated the relative importance of conceptual geological model uncertainty versus climate model uncertainty.

The objective of the present study is to assess the effects of climate model uncertainty and conceptual geological uncertainty for projection of future conditions with respect to different river flow and groundwater aspects.

\section{Study area and model setup}

\subsection{Study area}

The study site has an area of $465 \mathrm{~km}^{2}$ and is located in the central part of Zealand, Denmark (Fig. 1) where focus is given to the area covered by the Langvad Stream valley system. The model area is bounded by Køge Bay in the east and by Roskilde Fjord in the north. The area is relatively hilly, with maximum elevations of approximately $100 \mathrm{~m}$ above sea level. Land use within the model area is dominated by agriculture $(80 \%)$, while the remaining area is covered by forest $(10 \%)$, urban areas $(10 \%)$ and lakes $(<1 \%)$. The main aquifer in the area, the Limestone Formation, is overlain by Quaternary deposits of interchanging and discontinuous layers of clayey moraine till and fluvial sand. Groundwater is abstracted at six main well fields in the focus area and exported to Copenhagen for water supply. The study area is described in detail in Seifert et al. (2012).

\subsection{Model setup}

Based on the national water resource model developed by the Geological Survey of Denmark and Greenland (Henriksen et al., 2003; Højberg et al., 2008, 2013) a hydrological model of the catchment area has been developed. The model is constructed using the MIKE SHE/MIKE 11 modeling software (DHI, 2009a, b). MIKE SHE includes a range of alternative process descriptions and here the modules for evapotranspiration, overland flow, a two-layer description of the unsaturated zone, and the saturated zone including drains is used. The river model MIKE 11 links to MIKE SHE, so that water is exchanged between streams and the groundwater aquifers.

Six alternative geological models using between 3 and 12 hydrostratigraphical layers (Table 1) have been established (Seifert et al., 2012). The basis of the geological models comprises two national models ( $\mathrm{N} 1$ and $\mathrm{N} 2$ ), two regional models (R1 and R2) and two local models (L1 and L2). All models consist from bottom to top of Paleocene limestone, Paleocene clay and Quaternary deposits. In the more complex geological models the Quaternary unit is divided into several alternating sand and clay layers. The location of the limestone surface and the extent of the sand aquifers differ significantly between the geological models. The six geological models were incorporated into the hydrological model, resulting in six alternative hydrological models (Seifert et al., 2012). Horizontally, the models are discretized in $200 \times 200 \mathrm{~m}$ cells. Vertically, the numerical layers are discretized according to the geological layers, though in model N1 and N2 the three top layers are combined into one numerical layer. Between three and ten numerical layers are used in the six models.

The models are calibrated against hydraulic head and stream discharge data from 2000-2005 and validated in the period 1995-1999 (Seifert et al., 2012) where the validation period is characterized by a groundwater abstraction that is about $20 \%$ higher than in the calibration period. Generally, the simulation results for the validation period are slightly inferior to the results for the calibration period, but the statistical values have the same magnitude for the two periods. The calibration results (Table 1) reveal quite large differences in the match to hydraulic head (represented by the mean error, $\mathrm{ME}$, and the root mean square value, RMS), the stream discharge (given by the Nash-Sutcliffe coefficient, $E$, and the relative water balance error, $F_{\text {bal }}$ ) using the different geological models. Some models are more suitable for stream flow simulations (e.g., N2) while other models are stronger on hydraulic heads (e.g., L2). However, based on an integrated evaluation the calibration/validation statistics no model is generally superior to the others. More details on the model setup including historical climate data and model calibration and validation can be found in Seifert et al. (2012).

The period 1991-2010 is used as a reference to the future scenarios. In this period the abstraction decreased from 23 million $\mathrm{m}^{3} \mathrm{yr}^{-1}$ in 1990 to less than 15 million $\mathrm{m}^{3} \mathrm{yr}^{-1}$ in 2010. To minimize transient effects a constant groundwater abstraction of about 16 million $\mathrm{m}^{3} \mathrm{yr}^{-1}$ (based on average data from 2000-2005) is used for both the reference period and future scenarios. 
Table 1. Geological models of the Langvad Stream catchment area. Calibration statistics are indicated by the mean error (ME $\mathrm{TS})$ and root mean square error of hydraulic head time series $\left(\mathrm{RMS}_{\mathrm{TS}}\right)$, the Nash-Sutcliffe coefficient $(E)$ and the water balance $\left(F_{\text {bal }}\right)$ for stream discharge.

\begin{tabular}{lrrrrrr}
\hline Name & $\mathrm{R} 1$ & $\mathrm{R} 2$ & $\mathrm{~L} 1$ & $\mathrm{~L} 2$ & $\mathrm{~N} 1$ & $\mathrm{~N} 2$ \\
\hline $\begin{array}{l}\text { No. of hydro- } \\
\text { stratigraph. layers }\end{array}$ & 3 & 5 & 7 & 7 & 11 & 12 \\
No. of numerical & & & & & & \\
layers in model & & & & & & 10 \\
Reference & (Roskilde & (Roskilde & (Københavns & (Københavns & (Henriksen & (Højberg \\
& Amt, 2002) & Amt, 2003) & Energi, 2005) & Energi, 2005) & et al., 1998) & et al., 2008) \\
ME $_{\mathrm{TS}}(\mathrm{m})$ & -1.41 & -0.20 & 0.31 & -0.16 & 1.38 & -0.19 \\
$\mathrm{RMS}_{\mathrm{TS}}(\mathrm{m})$ & 6.52 & 3.12 & 2.08 & 2.01 & 4.41 & 4.82 \\
$E(-)$ & 0.58 & 0.58 & 0.17 & -0.12 & 0.63 & 0.75 \\
$F_{\text {bal }}(\%)$ & -17 & -8 & -2 & -2 & -2 & -2 \\
\hline
\end{tabular}

Table 2. Matrix of ENSEMBLES climate models with GCM-RCM pairings used for the climate models (GCM denotes global climate model, RCM denotes regional climate model). From Seaby et al. (2013).

\begin{tabular}{lcccc}
\hline GCM & HadCM3 & ECHAM5 & ARPEGE & BCM2 \\
RCM & & & & \\
\hline HadRM3 & $\mathbf{X}$ & $\mathbf{x}$ & & \\
REMO & & $\mathbf{X}$ & \\
RM5.1 & & $\mathbf{X}$ & $\mathbf{X}$ & $\mathbf{X}$ \\
HIRHAM5 & & & & \\
CLM & $\mathbf{X}$ & $\mathbf{X}$ & & \\
RACMO2 & & $\mathbf{X}$ & & $\mathbf{x}$ \\
RegCM3 & & $\mathbf{X}$ & & $\mathbf{X}$ \\
RCA3 & & &
\end{tabular}

\subsection{Climate data}

Climate projections representing the period 2081-2100 are obtained from Seaby et al. (2013) using results from 11 climate models from the ENSEMBLES matrix (Christensen et al., 2009) of global and regional climate model pairings (GCM-RCM), Table 2. Seaby et al. (2013) analyzed the impact of the length of the reference and the future periods and found that period lengths over 15 years appeared suitable for precipitation. Hence, comparing two 20 -year periods is assumed to be adequate for the particular study area.

The delta change (DC) method (Hay et al., 2000; van Roosmalen et al., 2007) is used as a downscaling approach on precipitation $(P)$, reference evapotranspiration $\left(\mathrm{ET}_{\text {ref }}\right)$ and temperature $(T)$. The delta change factors for Zealand are derived by comparing monthly mean values of past and future climate data from the climate models (Seaby, 2013). The model projections of future climate changes vary significantly with both drier and wetter future climate, indicated by delta change factors on precipitation, ranging between 0.83 and 1.17 on an annual basis. However, major differences be- tween the models are also found with respect to the seasonal signal. To obtain time series of future climate, observed records of $P$ and $\mathrm{ET}_{\text {ref }}$ in the control period (1991-2010) are multiplied by the monthly delta change factors $(\Delta P$ and $\left.\Delta \mathrm{ET}_{\text {ref }}\right)$, while the temperature delta change values $(\Delta T)$ are added to the observed time series of $T$. The reliability of the DC method for projecting changes has rightfully been questioned by Teutschbein and Seibert (2013) who found that more advanced methods were more reliable. In our specific case Seaby et al. (2013) compared the DC method with a double gamma distribution based scaling (DBS), showing that both methods were equally good in capturing the mean monthly as well as the seasonal climate characteristics in temperature, precipitation and potential evapotranspiration when tested against observed data for 1991-2010. Seaby (2013) further showed that when propagating climate projections for 2071-2100 through the same hydrological model type as used in our study, the results for the discharge and groundwater head characteristics used in our study are almost identical for the two bias correction methods. This confirms the results of van Roosmalen et al. (2011) and justifies the use of the simple DC method for our particular application.

Here, an ensemble of results based on eight RCMs and four GCMs are used and only one downscaling method is used. Using another ensemble of climate models or another downscaling method would probably affect the mean/median of the results. However, in the present study the results from different climate projections are only used for comparison against results obtained using different geological models, and not for predicting the actual changes in the hydrological system as a result of climate changes. Hence, the ensemble used here is assumed to represent the (unknown) full variability found in climate model projections. 


\section{Methodology}

Results from the six hydrological models forced by climate projections from the 11 climate models (total of 66 model simulations) are extracted and the variance caused by the geological model and the climate model is derived. The results are also compared to results representing the reference period 1991-2010 that covers both the calibration and validation periods, to quantify the changes in hydraulic head $(\Delta h)$ in the limestone aquifer in the focus area (Fig. 1), changes in stream discharge $(\Delta Q)$ at a downstream gauging station in the Langvad Stream system, travel time $(\Delta T)$ and capture zone area $\left(\Delta A_{\text {cap }}\right)$ for the well fields in the focus area. The change in hydrological variables is caused by climate change only as the geology is the same for both reference and scenario climate.

\subsection{Hydraulic head and stream discharge}

The mean hydraulic head $(h)$ in the limestone aquifer within the focus area is extracted from all model simulations and the change in hydraulic head $(\Delta h)$ as a result of changing climate is calculated.

A large part of the precipitation is expected to flow directly to the streams, either as surface runoff or through the drains, especially during the winter season. Hence, the total stream discharge is expected to be highly sensitive to changes in climate. In order to capture the effect of climate change on the groundwater-dominated base flow, stream discharge results from the summer period (June, July and August) are extracted at the downstream discharge station, st. 52.30 (see Fig. 1).

\subsection{Travel time}

Travel times from the water table to the well fields are estimated by forward particle tracking using MIKE SHE. Particles are initially located randomly in the upper 1-3 numerical layers depending on how the geology is represented by the numerical layers in the models. The sum of particles in the vertical direction is 200 particles per cell, resulting in about 2 million particles per model. The flow solution on which the particle tracking simulation is based is obtained by recycling the flow results for the simulation period (1991-2010 for the reference period and 2081-2100 for the future climate period). After 1000 years of simulation the end points are registered and particles with end points at the well fields are extracted. Since the thickness of the numerical layers vary considerably between the models, only particles originating from the upper $10 \mathrm{~m}$ of the saturated zone are used for the travel time assessment in order to get comparable results. The median travel time $(T)$ at each well field is calculated for each of the 11 future climate projections and for the reference climate. The changes in travel time $(\Delta T)$ from the reference climate to the future climate projections are also cal-

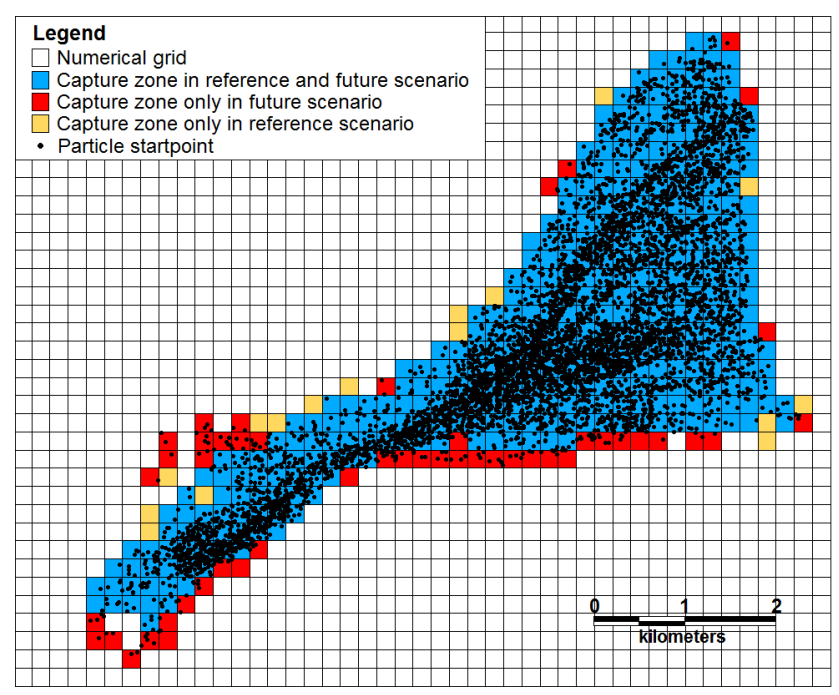

Figure 2. Methodology for estimation of and change in capture zone area for a well field.

culated. Precipitation may affect the hydraulic heads and the hydraulic gradients in a specific area which affects groundwater discharge and hence the flow velocity. Additionally, flow paths to the abstraction well may change as the size of the recharge area changes, see below. Climate change is therefore expected to impact travel time to the abstraction wells.

\subsection{Capture zone}

The capture zones to the well fields are also simulated by forward particle tracking where the particles are tracked for 1000 years as described above. Particles are initially located randomly in the upper layers and in all aquifers. Particles with end points at the well fields are extracted and the origin of the particles is projected to the 2-D horizontal plane. The capture zones are delineated as the grid cells that contain particle start locations (Fig. 2) and the capture area ( $\left.A_{\text {cap }}\right)$ is defined as the area of these grid cells. The change in capture zone area from the reference climate to a future climate is defined as the capture area included in the future climate simulation but not in the reference climate simulation $\left(\Delta A_{\text {cap }}\right)$. The location and shape of the capture zone depends on geological characteristics. However, it also depends on groundwater recharge since the water abstracted at the well corresponds to the spatially integrated groundwater recharge which in turn depends on precipitation. Thus, the less groundwater recharge, the larger the capture zone will be. Therefore, climate change is expected to affect the capture zone area. 
a)
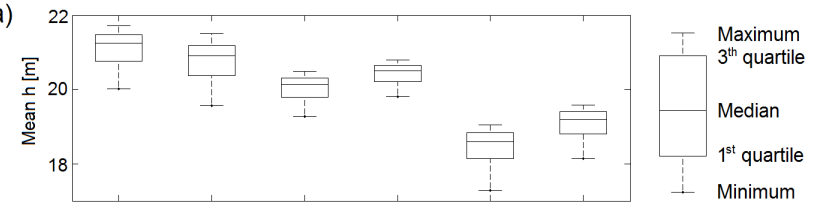

b)

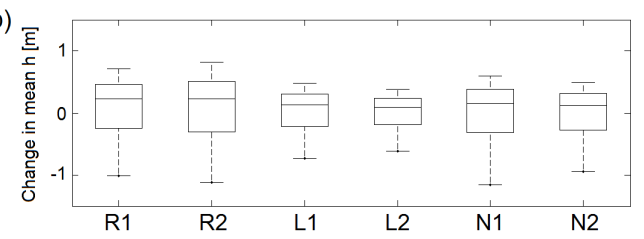

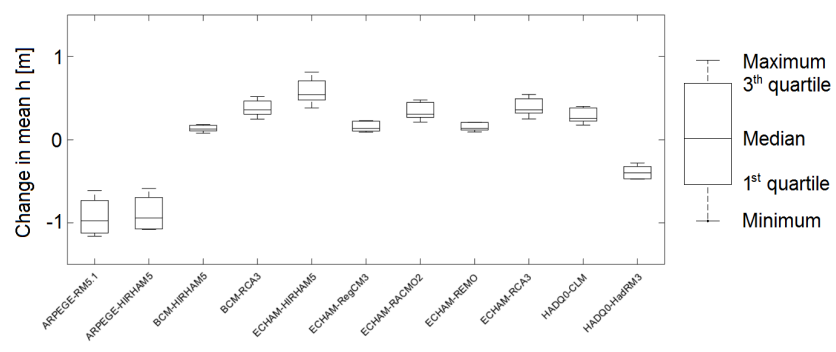

Figure 4. Simulated change in mean hydraulic head of the limestone aquifer in the focus area using six geological models and 11 climate models.

When the changes in hydraulic head are compared across geological models (Fig. 3b and Table 4), it is clear that the effect of geology is relatively small. Some of the geological models are more sensitive to the changes in climate (e.g., R2) than others (e.g., L2), represented by the length of the whiskers for each geological model in Fig. 3. Changes in hydraulic head that are up to twice as high are found for the most sensitive models compared to the models that are relatively insensitive. However, larger differences in hydraulic head change are found across climate models represented by the difference between the upper and lower end of the whiskers. A two-factor analysis of variance shows that the climate model has more impact on the change in hydraulic head than the geological model, as $F_{\text {climate }}=104.6$ $\left(\gg F_{\text {crit }}=2.0\right)$ and $F_{\text {geology }}=1.2\left(<F_{\text {crit }}=2.4\right)$. The same conclusion can also be drawn from Table 4 by comparing the standard deviation on the changes in hydraulic head $(h)$ caused by geological models $(0.11 \mathrm{~m})$ with the standard deviation caused by climate models $(0.52 \mathrm{~m})$.

Figure 4 also shows that the direction and the magnitude of the change in hydraulic head depend primarily on the climate model. Three of the climate models result in decreasing hydraulic heads, with values ranging between -0.28 and $-1.16 \mathrm{~m}$ depending on the geological model and the climate model. The remaining eight climate models all result in increasing hydraulic heads in the limestone aquifer between 0.08 and $0.82 \mathrm{~m}$.

From Fig. 4 it is also observed that the difference between the head results from the six geological models is larger when the mean change in hydraulic head caused by climate changes increases in positive or negative direction. For example, climate model BCM-HIRHAM5 that is characterized by delta change values for precipitation close to 1 during the winter season (0.99-1.13) results in a small change in mean hydraulic head and the response from the six geological models is almost the same. In contrast, relatively large differences are found between the response from the geological models when the climate model ECHAM-HIRHAM5 is used. Here, the delta change values during winter, where groundwater primarily is generated, are relatively large (up to 1.38) and the mean change in hydraulic head is also relatively large. 
Table 3. Simulated mean hydraulic head in the limestone aquifer in the focus area for the reference scenario and the scenario climates. Changes in mean hydraulic head from reference to scenario climate are listed in brackets. "Mean geology" and "SD geology" are the average and the standard deviation of the results from the hydrological models for each climate scenario. "Mean climate" and "SD climate" the average and the standard deviation of the results from the different climate models used in each hydrological model.

\begin{tabular}{|c|c|c|c|c|c|c|c|c|}
\hline$h$ mean, $\mathrm{m}$ & $\mathrm{R} 1$ & $\mathrm{R} 2$ & L1 & $\mathrm{L} 2$ & N1 & $\mathrm{N} 2$ & $\begin{array}{l}\text { Mean } \\
\text { geology }\end{array}$ & $\begin{array}{l}\text { SD } \\
\text { geology }\end{array}$ \\
\hline Reference climate & 21.0 & 20.7 & 20.0 & 20.4 & 18.5 & 19.1 & 19.9 & 1.0 \\
\hline ARPEGE-RM5.1 & $\begin{array}{l}20.0 \\
(-1.01)\end{array}$ & $\begin{array}{l}19.6 \\
(-1.12)\end{array}$ & $\begin{array}{l}19.3 \\
(-0.73)\end{array}$ & $\begin{array}{l}19.8 \\
(-0.61)\end{array}$ & $\begin{array}{l}17.3 \\
(-1.16)\end{array}$ & $\begin{array}{l}18.1 \\
(-0.94)\end{array}$ & $\begin{array}{l}19.0 \\
(-0.93)\end{array}$ & $\begin{array}{l}1.07 \\
(0.22)\end{array}$ \\
\hline ARPEGE-HIRHAM5 & $\begin{array}{l}20.0 \\
(-1.00)\end{array}$ & $\begin{array}{l}19.6 \\
(-1.07)\end{array}$ & $\begin{array}{l}19.3 \\
(-0.69)\end{array}$ & $\begin{array}{l}19.8 \\
(-0.59)\end{array}$ & $\begin{array}{l}17.4 \\
(-1.08)\end{array}$ & $\begin{array}{l}18.2 \\
(-0.88)\end{array}$ & $\begin{array}{l}19.1 \\
(-0.89)\end{array}$ & $\begin{array}{l}1.04 \\
(0.21)\end{array}$ \\
\hline BCM-HIRHAM5 & $\begin{array}{l}21.2 \\
(0.17)\end{array}$ & $\begin{array}{l}20.9 \\
(0.19)\end{array}$ & $\begin{array}{l}20.1 \\
(0.11)\end{array}$ & $\begin{array}{l}20.5 \\
(0.08)\end{array}$ & $\begin{array}{l}18.6 \\
(0.14)\end{array}$ & $\begin{array}{l}19.2 \\
(0.12)\end{array}$ & $\begin{array}{l}20.1 \\
(0.13)\end{array}$ & $\begin{array}{l}1.00 \\
(0.04)\end{array}$ \\
\hline BCM-RCA3 & $\begin{array}{l}21.5 \\
(0.47)\end{array}$ & $\begin{array}{l}21.2 \\
(0.52)\end{array}$ & $\begin{array}{l}20.3 \\
(0.31)\end{array}$ & $\begin{array}{l}20.7 \\
(0.25)\end{array}$ & $\begin{array}{l}18.8 \\
(0.40)\end{array}$ & $\begin{array}{l}19.4 \\
(0.33)\end{array}$ & $\begin{array}{l}20.3 \\
(0.38)\end{array}$ & $\begin{array}{l}1.02 \\
(0.10)\end{array}$ \\
\hline ECHAM-HIRHAM5 & $\begin{array}{l}21.7 \\
(0.71)\end{array}$ & $\begin{array}{l}21.5 \\
(0.82)\end{array}$ & $\begin{array}{l}20.5 \\
(0.48)\end{array}$ & $\begin{array}{l}20.8 \\
(0.39)\end{array}$ & $\begin{array}{l}19.0 \\
(0.60)\end{array}$ & $\begin{array}{l}19.6 \\
(0.49)\end{array}$ & $\begin{array}{l}20.5 \\
(0.58)\end{array}$ & $\begin{array}{l}1.05 \\
(0.16)\end{array}$ \\
\hline ECHAM-RegCM3 & $\begin{array}{l}21.2 \\
(0.23)\end{array}$ & $\begin{array}{l}20.9 \\
(0.23)\end{array}$ & $\begin{array}{l}20.1 \\
(0.13)\end{array}$ & $\begin{array}{l}20.5 \\
(0.09)\end{array}$ & $\begin{array}{l}18.6 \\
(0.14)\end{array}$ & $\begin{array}{l}19.2 \\
(0.11)\end{array}$ & $\begin{array}{l}20.1 \\
(0.15)\end{array}$ & $\begin{array}{l}1.02 \\
(0.06)\end{array}$ \\
\hline ECHAM-RACMO2 & $\begin{array}{l}21.5 \\
(0.45)\end{array}$ & $\begin{array}{l}21.2 \\
(0.48)\end{array}$ & $\begin{array}{l}20.3 \\
(0.28)\end{array}$ & $\begin{array}{l}20.6 \\
(0.21)\end{array}$ & $\begin{array}{l}18.8 \\
(0.34)\end{array}$ & $\begin{array}{l}19.4 \\
(0.27)\end{array}$ & $\begin{array}{l}20.3 \\
(0.34)\end{array}$ & $\begin{array}{l}1.04 \\
(0.11)\end{array}$ \\
\hline ECHAM-REMO & $\begin{array}{l}21.2 \\
(0.21)\end{array}$ & $\begin{array}{l}20.9 \\
(0.21)\end{array}$ & $\begin{array}{l}20.1 \\
(0.13)\end{array}$ & $\begin{array}{l}20.5 \\
(0.10)\end{array}$ & $\begin{array}{l}18.6 \\
(0.15)\end{array}$ & $\begin{array}{l}19.2 \\
(0.12)\end{array}$ & $\begin{array}{l}20.1 \\
(0.15)\end{array}$ & $\begin{array}{l}1.01 \\
(0.05)\end{array}$ \\
\hline ECHAM-RCA3 & $\begin{array}{l}21.5 \\
(0.50)\end{array}$ & $\begin{array}{l}21.2 \\
(0.55)\end{array}$ & $\begin{array}{l}20.3 \\
(0.33)\end{array}$ & $\begin{array}{l}20.7 \\
(0.25)\end{array}$ & $\begin{array}{l}18.8 \\
(0.40)\end{array}$ & $\begin{array}{l}19.4 \\
(0.32)\end{array}$ & $\begin{array}{l}20.3 \\
(0.39)\end{array}$ & $\begin{array}{l}1.03 \\
(0.11)\end{array}$ \\
\hline HADQ0-CLM & $\begin{array}{l}21.4 \\
(0.39)\end{array}$ & $\begin{array}{l}21.1 \\
(0.40)\end{array}$ & $\begin{array}{l}20.2 \\
(0.24)\end{array}$ & $\begin{array}{l}20.6 \\
(0.18)\end{array}$ & $\begin{array}{l}18.7 \\
(0.28)\end{array}$ & $\begin{array}{l}19.3 \\
(0.23)\end{array}$ & $\begin{array}{l}20.2 \\
(0.29)\end{array}$ & $\begin{array}{l}1.03 \\
(0.09)\end{array}$ \\
\hline HADQ0-HadRM3 & $\begin{array}{l}20.6 \\
(-0.39)\end{array}$ & $\begin{array}{l}20.2 \\
(-0.47)\end{array}$ & $\begin{array}{l}19.7 \\
(-0.32)\end{array}$ & $\begin{array}{l}20.1 \\
(-0.28)\end{array}$ & $\begin{array}{l}18.0 \\
(-0.47)\end{array}$ & $\begin{array}{l}18.7 \\
(-0.41)\end{array}$ & $\begin{array}{l}19.6 \\
(-0.39)\end{array}$ & $\begin{array}{l}1.02 \\
(0.08)\end{array}$ \\
\hline Mean climate & $\begin{array}{l}21.1 \\
(0.07)\end{array}$ & $\begin{array}{l}20.7 \\
(0.07)\end{array}$ & $\begin{array}{l}20.0 \\
(0.02)\end{array}$ & $\begin{array}{l}20.4 \\
(0.01)\end{array}$ & $\begin{array}{l}18.4 \\
(-0.02)\end{array}$ & $\begin{array}{l}19.1 \\
(-0.02)\end{array}$ & $\begin{array}{l}20.0 \\
\left(0.02^{\mathrm{a}}\right)\end{array}$ & $\begin{array}{l}1.03 \\
\left(0.11^{b}\right)\end{array}$ \\
\hline SD climate & $\begin{array}{l}0.60 \\
(0.60)\end{array}$ & $\begin{array}{l}0.66 \\
(0.66)\end{array}$ & $\begin{array}{l}0.42 \\
(0.42)\end{array}$ & $\begin{array}{l}0.34 \\
(0.34)\end{array}$ & $\begin{array}{l}0.60 \\
(0.60)\end{array}$ & $\begin{array}{l}0.49 \\
(0.49)\end{array}$ & $\begin{array}{l}0.52 \\
\left(0.52^{\mathrm{c}}\right)\end{array}$ & $\begin{array}{l}1.07 \\
\left(0.51^{\mathrm{a}}\right)\end{array}$ \\
\hline
\end{tabular}

${ }^{a}$ Mean and standard deviation based on all the numbers in the matrix. ${ }^{b}$ Mean of the standard deviations of geological models. ${ }^{\mathrm{c}}$ Mean of the standard deviations of climate models.

The same tendency is found for the other climate models. Hence, since the mean change in hydraulic head is expected to depend on the changes in precipitation and evapotranspiration, the mean standard deviation on heads from the different geological models are compared to the change in the net precipitation (here represented by precipitation minus reference evapotranspiration, $P-\mathrm{ET}_{\text {ref }}$ ). The result (Fig. 5) reveals a clear linear tendency for increasing uncertainty caused by the geological model as the changes projected by the climate model differ from the present climate, where the model was calibrated. Hence, as the future climate moves away from the baseline, the more sensitive the results are with respect to the conceptual geological model and the higher the projection uncertainty might be expected to be.

\subsection{Uncertainty on stream discharge}

Figure 6a shows a box plot of the simulated mean summer stream discharge at the downstream discharge station (st. 52.30, see Fig. 1). The projection of mean summer discharge depends to a large degree on the geological model, with lower values for the local models (L1 and L2) and higher values for the regional models (R1 and R2). The uncertainty caused by the climate model, represented by the length of the whiskers, is also significant with a tendency for larger uncertainties for larger absolute mean summer discharge. The ratio between the standard deviation and the median value is almost constant for the six models. However, the geological model has the strongest impact, resulting in a standard deviation of $0.21 \mathrm{~m}^{3} \mathrm{~s}^{-1}$ compared to a value of $0.14 \mathrm{~m}^{3} \mathrm{~s}^{-1}$ caused by climate uncertainty (Table 4 ). 
Table 4. Results of variance analysis with respect to climate models and geological models on (1) absolute mean values and (2) changes in mean values compared to results obtained using reference climate with respect to hydraulic head, discharge (annual and summer distance), travel time and catchment area. All variance components (columns denoted "Geology" and "Climate") are presented as standard deviations. The column "Mean change" denotes the projected mean change.

\begin{tabular}{llr|r|rrr}
\hline & & \multicolumn{2}{c}{ Absolute values } & \multicolumn{2}{c}{ Change relative to reference climate } \\
\cline { 3 - 7 } & Location & Geology & Climate & Mean change & Geology & Climate \\
\hline Head, $\mathrm{m}$ & Focus area & 1.03 & 0.52 & 0.02 & 0.11 & 0.52 \\
\hline Annual distance, & st. 52.30 & 0.08 & 0.32 & 0.08 & 0.01 & 0.32 \\
$\mathrm{~m}^{3} \mathrm{~s}^{-1}$ & & & & & & \\
Summer distance, $^{3}$ & st. 52.30 & 0.21 & 0.14 & 0.00 & 0.05 & 0.14 \\
$\mathrm{~m}^{3} \mathrm{~s}^{-1}$ & & & & & & \\
\hline Travel time, & Assermølle & 30.7 & 6.4 & -0.2 & 4.6 & 6.4 \\
years & Gevninge & 60.3 & 4.1 & 0.6 & 2.5 & 4.1 \\
& Hule Mølle & 36.4 & 4.9 & 1.6 & 7.1 & 4.9 \\
& Kornerup & 81.0 & 2.8 & 0.6 & 2.7 & 2.8 \\
& Lavringe & 58.5 & 2.4 & 1.5 & 2.4 & 2.4 \\
& Rams $\varnothing$ & 66.5 & 4.2 & 0.8 & 3.4 & 4.2 \\
\hline Catchment area, & Assermølle & 13.0 & 1.6 & 2.4 & 1.4 & 1.6 \\
$\mathrm{~km}^{2}$ & Gevninge & 1.6 & 0.6 & 0.8 & 0.5 & 0.6 \\
& Hule Mølle & 6.2 & 0.5 & 0.7 & 0.5 & 0.5 \\
& Kornerup & 15.9 & 1.0 & 2.9 & 1.6 & 1.0 \\
& Lavringe & 6.7 & 0.3 & 0.9 & 0.4 & 0.3 \\
& Rams $\varnothing$ & 10.5 & 0.4 & 1.0 & 0.5 & 0.4 \\
\hline
\end{tabular}

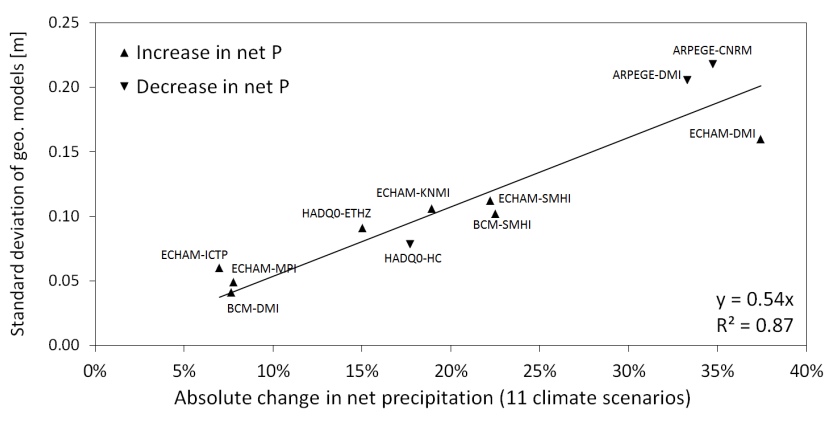

Figure 5. Standard deviations of the change in hydraulic head from the geological models (Table 3), compared with the change in the reference net precipitation $\left(P-\mathrm{ET}_{\text {ref }}\right)$.

In Fig. $6 \mathrm{~b}$ the box plot of the change in summer discharge from the reference period to the future scenarios shows that the response in summer stream discharge from the different geological models is similar when the median value is considered. On average, the mean change in summer discharge is zero; see Table 4 . The difference between upper and lower whiskers indicates that the impact of climate models on the projection of the change in summer stream discharge is significant, with changes from -0.3 to $0.3 \mathrm{~m}^{3} \mathrm{~s}^{-1}$. The standard deviations listed in Table 4 show that the uncertainty on the change in summer discharge caused by geology is $0.05 \mathrm{~m}^{3} \mathrm{~s}^{-1}$, whereas the uncertainty caused by the climate model amounts to $0.14 \mathrm{~m}^{3} \mathrm{~s}^{-1}$, i.e., the climate uncertainty is largest although the contributions are in the same order of magnitude. With respect to annual mean discharge $\left(Q_{\mathrm{a}}\right)$ (see Table 4) climate uncertainty is much higher than geological uncertainty, especially when the change in discharge is considered. This shows that the uncertainty on annual mean stream discharge is much more sensitive to climate change than to the geological model. Summer discharge, where groundwater-river interactions are relatively more important, is much more affected by the uncertainty in geology.

\subsection{Uncertainty on travel time}

The travel time of the groundwater abstracted at each of the six well fields in the focus area has been quantified and listed in Table 4. The results obtained at the six wells fields are similar, and therefore only results on travel times and changes in travel time are illustrated for one of the well fields, Lavringe; see Fig. 7.

The absolute travel times (Fig. 7a) depend strongly on the geological model. Median travel times from fewer than 50 years to nearly 200 years are found for the different geological models. Based on results from all six well fields, differences in median travel time of up to a factor of 10 are found with a tendency for shorter travel times using the geological model R2 and larger travel times using N1. Compared to the results for hydraulic head and stream discharge, 
a)
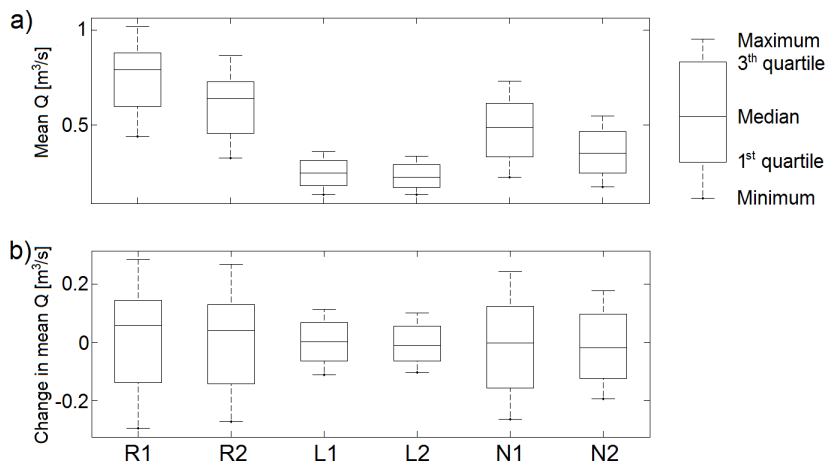

Figure 6. (a) Box plot of the simulated mean summer stream discharge $\left(Q_{\mathrm{s}}\right)$ in a downstream discharge station (st. 52.30) using input from 11 climate models, and (b) box plot of the change in $Q_{\mathrm{s}}$ from reference to future scenarios.

a)
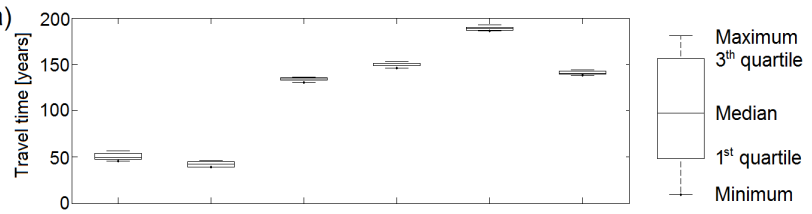

b)

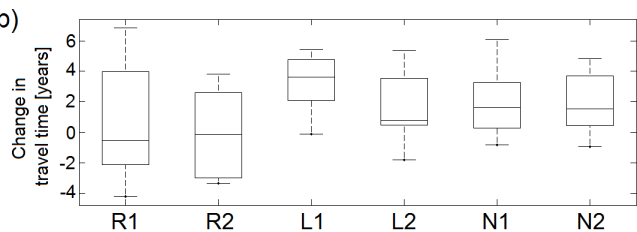

Figure 7. (a) Box plot of the simulated median travel time to Lavringe well field, and (b) box plot of the percentage change in median travel time from reference to future scenarios.

Figs. 3a and 6a, respectively, it is clear that the effect of the geological model is crucial when travel times are considered. The standard deviations on geological models, in the order of $30-80$ years (Table 4 ), are significantly higher than the standard deviations on climate models, in the range of 2-6 years. Hence, the climate model has limited impact on the absolute travel time predictions. This indicates that climate changes do not notably change the flow pattern that controls the flow paths and hereby the travel time of the groundwater from the surface to, e.g., an abstraction well.

If changes in travel time from the reference to future climate (Fig. 7b and Table 4) are considered, it is seen that the role of the geological model on the change in travel time is similar to the impact of climate change. The mean standard deviation on the change caused by climate models and geological models are of the same magnitude with values of approximately 2 years for Lavringe well field. At the other well fields comparative results are also obtained with values in the range of 2.5 to 7.1 years (Table 4). This is in contrast to the results for hydraulic head and stream discharge where the climate signal was the most important factor for the changes.
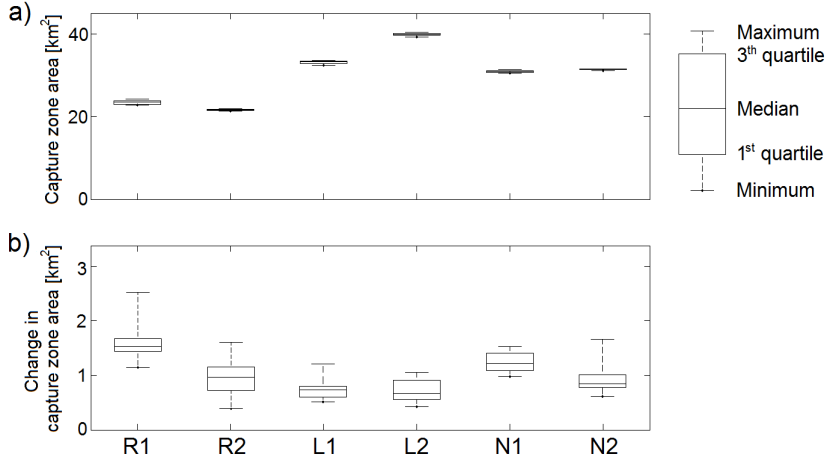

Figure 8. (a) Box plot of the simulated capture zone area for Lavringe well fields and (b) box plot of the percentage change in capture zone area from reference to future scenarios.

\subsection{Uncertainty on capture zones}

Figure 8a shows results on capture zone area from Lavringe well field. Capture zone areas between 20 and $40 \mathrm{~km}^{2}$ are found for the different geological models. If all six well fields in the focus area (Fig. 1) are considered, the capture zone area varies with a factor of 2-3 using different geological models. In comparison, the effect of climate model on the uncertainty is relatively small. For most models the change in capture zone area caused by climate change (Fig. 8b) amounts to less than $2 \mathrm{~km}^{2}$, corresponding to less than $10 \%$ of the reference area. Hence, the results with regard to the capture zone area are very similar to those found for travel time (Fig. 7).

The impacts of climate model and conceptual geology on the capture zone locations are illustrated for Gevninge and Lavringe well fields in Fig. 9. On the left side, the uncertainty of the capture zones using different geological models is illustrated. To the right, the impact of using different climate models is shown. It is clear that relatively large differences between capture zone areas are found when multiple geological models are used, whereas almost identical capture zones are predicted for the 11 climate models.

\section{Discussion}

In Table 4 the uncertainties caused by the climate model and geological model are summarized, both with respect to the absolute level in the future situation and the change from the reference to the future situation. The results on the absolute values reflect the differences in model calibration, which in turn affects the results in the future climate. It should be noted that no calibration has been carried out with respect to travel time and catchment area.

For projections of hydraulic head, the impact of geological model and climate model on the uncertainty on absolute heads is in the same order of magnitude with differences in standard deviations of about a factor of 2 . If the changes in 


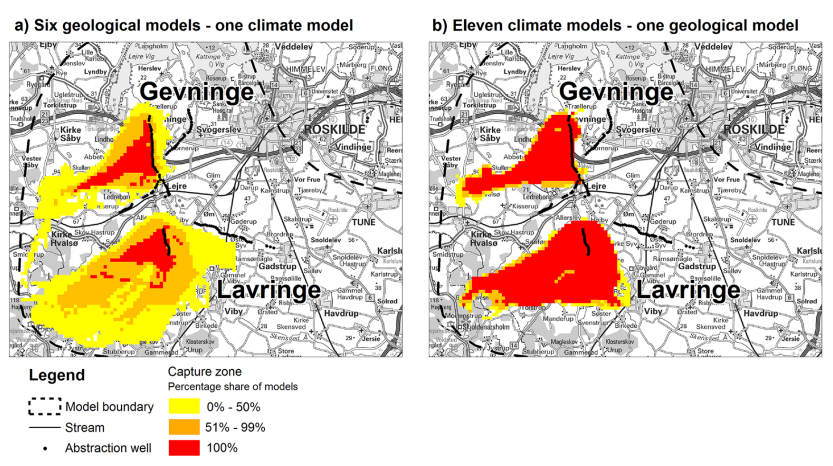

Figure 9. Uncertainty of catchment areas for two well fields using (a) six geological models with the same climate model, and (b) 11 climate models with the same geological model.

hydraulic heads from reference to future climate are considered, the climate model is more important for the uncertainty than the geology (difference of a factor of 5). Hence, in this case the choice of climate model is very important for the hydrological projection and the uncertainty on the changes in future hydraulic head levels.

The results for summer stream discharge $\left(Q_{\mathrm{s}}\right)$ are somewhat similar. The uncertainty on the absolute discharge is almost equally controlled by the geological model and the climate model, which is comparable to the results for hydraulic head. If the change in summer discharge is considered, the uncertainty caused by the climate model is a factor of 3 higher than geological uncertainty. Hence, climate model uncertainty is most important but both sources of uncertainty are significant. With respect to annual mean discharge $\left(Q_{\mathrm{a}}\right)$, the impact from climate model uncertainties in the absolute discharge is a factor of 4 higher than the geological uncertainty. If the change from reference to future period is considered, the results are even more clear. Almost all the uncertainty is caused by the climate model, whereas the geology has almost no impact on the results (standard deviations of $0.01 \mathrm{~m}^{3} \mathrm{~s}^{-1}$ vs. $0.32 \mathrm{~m}^{3} \mathrm{~s}^{-1}$ ). Therefore, the climate model projection is extremely important for results on future annual mean stream discharge. The relatively small impact of the geological model is probably explained by the clayey top soils in the catchment that cause discharge to be dominated by shallow flow components such as overland flow and drain flow, especially in the wet season (winter).

The uncertainty on absolute travel time (left two columns in Table 4) is dominated by the geological model with standard deviations of up to about 80 years, whereas the uncertainties due to climate model only amount to a few years. Hence, in this case the geological model uncertainty is by far the most important source of uncertainty and the impact of climate model uncertainty can almost be ignored. However, the uncertainties in the changes (the column to the right) caused by geology is in the same order of magnitude as the impact from climate model. The same type of results is ob- tained as for capture zones (Fig. 8). The geological model dominates the uncertainty on the absolute capture zone area while the uncertainties in geology and climate have a comparable, and relatively small, effect on the change in capture zone location.

It should be noted that travel time and capture zone location were not included in the model calibration where only observations on hydraulic head and stream discharge were matched by the models. Hence, travel time and capture area were not constrained against a common target and larger differences between the results from the six models can therefore be expected. Additionally, only model parameters (e.g., hydraulic conductivity) but not the geological structure were adjusted to fit the observations, and possible structural errors in the geological models are therefore, at least partially, compensated for by the estimated model parameters. Hence, larger differences are expected between model predictions of travel time and capture zone, especially since the geological structure has been shown to be crucial for variables as travel time and capture zone that depend on flow path (Seifert et al., 2008; He et al., 2013).

It was also found that when the models are used for simulating conditions beyond the calibration base, i.e., used to simulate situations or type of data, which they have not been calibrated against, the differences in the geological models become more important and significant differences in the model results should be expected. Hence, the uncertainty caused by the conceptual geological model increases as the climate moves away from the baseline conditions.

Our findings are based on results from a specific case study with specific geological conditions and hence the general applicability of our conclusions for other locations needs to be considered with caution. As we are not aware of other studies that have reported results from comparison of climate model uncertainty and conceptual geological model uncertainty we are not able to provide firm generic conclusions on this specific aspect. However, our findings confirm the conclusions of previous studies that conceptual geological uncertainty is an important source of uncertainty in groundwater modeling (Neumann, 2003; Bredehoeft, 2005) and that it becomes more and more dominating compared to other sources the further away model predictions are from the calibration base (Refsgaard et al., 2012).

The fact that climate change uncertainty dominates over conceptual geological uncertainty for projections of groundwater heads and river discharge, while the opposite is the case for the projection of groundwater travel time and capture zones, clearly illustrates the context dependency of uncertainty propagation (Refsgaard et al., 2013), i.e., that climate uncertainty may be amplified and dominate in some cases but may be reduced to negligible importance in other cases. Similar conclusions were drawn by Velázquez et al. (2013) where several hydrological models with different structures were forced by climate projections from several climate models. They found that the uncertainty on climate change im- 
pacts on high flows were dominated by climate model uncertainty, while hydrological model structure uncertainty contributed significantly to low flows. Hence, our results on the travel times and capture zones are examples of where climate change uncertainty does not matter in practice (Refsgaard et al., 2013).

\section{Conclusions}

Based on hydrological model simulation using a combination of six geological models and projections from 11 climate models, the following conclusions are derived. (1) Climate model uncertainty is important for projection of hydraulic head and stream discharge. Especially for stream discharge, the uncertainty is dominated by the climate model. (2) Geological model uncertainty is important for projection of hydraulic head and the uncertainty becomes larger as the climate signal moves away from the baseline conditions. (3) Geological model uncertainty has a relatively small effect on the projections of stream discharge, even though summer stream discharge is analyzed where groundwaterriver interactions control a relatively high fraction of the total discharge. (4) The uncertainty on travel times and capture zones to well fields is dominated by geological model uncertainty. This uncertainty is controlled by the geological structure which is not constrained during the calibration process. The impact and hence the choice of climate model is relatively insignificant.

Acknowledgements. This work was funded by a grant from the Danish Strategic Research Council for the project Hydrological Modelling for Assessing Climate Change Impacts at different Scales (HYACINTS - www.hyacints.dk) under contract DSF-EnMi 2104-07-0008. Lauren Seaby, Geological Survey of Denmark and Greenland, is acknowledged for providing the delta change factors used for downscaling the results from the climate models.

Edited by: J. Seibert

\section{References}

Bastola, S., Murphy, C., and Sweeny, J.: The role of hydrological modelling uncertainties in climate change impact assessments of Irish river catchments, Adv. Water Resour., 34, 562-576, 2011.

Bredehoeft J.: The conceptualization model problem - Surprise, Hydrogeol. J., 13, 37-46, 2005.

Christensen, J. H., Rummukainen, M., and Lenderink, G.: Formulation of very-high-resolution regional climate model ensembles for Europe [Research Theme 3], ENSEMBLES: Climate Change and its Impacts: Summary of research and results from the ENSEMBLES project, Met Office Hadley Centre, UK, 47-58, 2009.

Déqué, M., Rowell, D. P., Lüthi, D., Giorgi, F., Christensen, J.H., Rockel, B., Jacob, D., Kjellström, E., de Castro, M., and van den
Hurk, B.: An Intercomparison of Regional Climate Model Simulations for Europe: Assessing Uncertainties in Model Predictions, Clim. Change, 81, 53-70, 2007.

DHI Water and Environment (DHI): MIKE SHE User manual, vol. 1; user guide, and vol. 2: reference guide, Institut for Vand andMilljo, available at: http://www.hydroasia.org (last access: 1 February 2013), DHI, Hørsholm, Denmark, 2009a.

DHI Water and Environment (DHI): MIKE 11, A modelling system for rivers and channels, user guide and reference manual, Institut for Vand and Milljo, available at: http://www.hydroasia.org (last access: 1 February 2013), DHI, Hørsholm, Denmark, 2009 b.

Dobler, C., Hagemann, S., Wilby, R. L., and Stötter, J.: Quantifying different sources of uncertainty in hydrological projections in an Alpine watershed, Hydrol. Earth Syst. Sci., 16, 4343-4360, doi:10.5194/hess-16-4343-2012, 2012.

Foley, A. M.: Uncertainty in regional climate modelling: A review, Prog. Phys. Geog., 34, 647-670, 2010.

Hay, L. E., Wilby, R. L., and Leavesley, G. H.: A comparison of delta change and downscaled GCM scenarios for three mountainous basins in the United States, J. Am. Water Resour. As. 36, 387-398, 2000.

Hawkins, E. and Sutton, R.: The potential to narrow uncertainty in projections of regional precipitation change, Clim. Dynam., 37, 407-418, doi:10.1007/s00382-010-0810-6, 2011.

He, X., Sonnenborg, T. O., Jørgensen, F., Høyer, A.-S., Møller, R. R., and Jensen, K. H.: Analyzing the effects of geological and parameter uncertainty on prediction of groundwater head and travel time, Hydrol. Earth Syst. Sci., 17, 3245-3260, doi:10.5194/hess17-3245-2013, 2013.

Henriksen H. J., Troldborg, L., Nyegaard, P., Sonnenborg, T. O., Refsgaard, J. C., and Madsen, B.: Methodology for construction, calibration and validation of a national hydrological model for Denmark, J. Hydrol., 280, 52-71, 2003.

Højberg A. L., Troldborg, L. Nyegaard, P., Ondraeck, M., Stisen, S., Christensen, B. S. B., and Nørgaard, A.: National Vandressource model - Sjælland, Lolland, Falster og Møn - Opdatering januar 2008, GEUS Rapport 2008/65, Geological Survey of Denmark and Greenland, Copenhagen, Denmark, 2008.

Højberg, A. L., Troldborg, L., Stisen, S., Christensen, B. S. B., and Henriksen, H. J.: Stakeholder driven update and improvement of a national water resources model, Environ. Model. Softw., 40, 202-213, doi:10.1016/j.envsoft.2012.09.010, 2013.

IPCC: Climate Change 2007: Impacts, Adaptation and Vulnerability. Contribution of Working Group II to the Fourth Assessment Report of the Intergovernmental Panel on Climate Change, edited by: Parry, M. L., Canziani, O. F., Palutikof, J. P., van der Linden, P. J., and Hanson, C. E., Cambridge University Press, Cambridge, UK, 976 pp., 2007.

IPCC: Climate Change 2013: The Physical Science Basis, Contribution of Working Group I to the Fifth Assessment Report of the Intergovernmental Panel on Climate Change, edited by: Stocker, T. F., Qin, D., Plattner, G.-K., Tignor, M., Allen, S. K., Boschung, J., Nauels, A., Xia, Y., Bex, V., and Midgley, P. M., Cambridge University Press, Cambridge, United Kingdom and New York, NY, USA, 1535 pp., 2013.

Kjellström, E., Nikulin, G., Hansson, U., Strandberg, G., and Ullerstig, A.: 21st century changes in the European climate: uncertainties derived from an ensemble of regional climate 
model simulations, Tellus A, 63, 24-40, doi:10.1111/j.16000870.2010.00475.x. (last access: 1 November 2012), 2011.

Minville, M., Brisette, F., and Leconte, R.: Uncertainty of the impact of climate change on the hydrology of a Nordic watershed, J. Hydrol., 358, 70-83, 2008.

Neumann, S. P.: Maximum likelihood Bayesian averaging of uncertain model predictions, Stoch. Env. Res. Risk A., 17, 291-305, 2003.

Poulin, A., Brisette, F., Leconte, R., Arsenault, R., and Malo, J. S.: Uncertainty of hydrological modelling in climate change impact studies in a Canadian, snow-dominated river basin, J. Hydrol., 409, 626-636, 2011.

Refsgaard, J. C., van der Sluijs, J. P., Højberg, A. L., and Vanrolleghem, P. A.: Uncertainty in the environmental modelling process - A framework and guidance, Environ. Model. Softw., 22, 1543-1556, 2007.

Refsgaard, J. C., Christensen, S., Sonnenborg, T. O., Seifert, D., Højberg, A. L., and Troldborg, L.: Review of strategies for handling geological uncertainty in groundwater flow and transport modelling, Adv. Water Res., 36, 36-50, 2012.

Refsgaard, J. C., Arnbjerg-Nielsen, K., Drews, M., Halsnæs, K., Jeppesen, E., Madsen, H., Markandya, A., Olesen, J. E., Porter, J. R., and Christensen, J. H.: The role of uncertainty in climate change adaptation strategies - A Danish water management example, Mitigation and Adaptation Strategies for Global Change, 18, 337-359, 2013.

Seaby, L. P.: Uncertainty in Hydrological Change Modelling, Ph.D. Thesis, GEUS Report 2013/58, available at: http://hyacints. dk/xpdf/lps_phd_thesis_2013_web.pdf, last access: 1 December 2013.
Seaby, L. P., Refsgaard, J. C., Sonnenborg, T. O., Stisen, S., Christensen, J. H., and Jensen, K. H.: Assessment of robustness and significance of climate change signals for an ensemble of distribution-based scaled climate projections, J. Hydrol., 486, 479-493, doi:10.1016/j.jhydrol.2013.02.015, 2013.

Seifert, D., Sonnenborg, T. O., Scharling, P., and Hinsby, K.: Use of alternative con-ceptual models to assess the impact of a buried valley on groundwater vulnerability, Hydrogeol. J., 16, 659-674, 2008.

Seifert, D., Sonnenborg, T. O., Refsgaard, J. C., Højberg, A. L., and Troldborg, L.: Assessment of hydrological model predictive ability given multiple conceptual geological models, Water Resour. Res., 48, W06503, doi:10.1029/2011WR011149, 2012.

Teutschbein, C. and Seibert, J.: Is bias correction of regional climate model (RCM) simulations possible for nonstationary conditions?, Hydrol. Earth Syst. Sci., 17, 5061-5077, doi:10.5194/hess-17-5061-2013, 2013.

van Roosmalen, L., Christensen, B. S. B., and Sonnenborg, T. O.: Regional differences in climate change impacts on groundwater and stream discharge in Denmark, Vadose Zone J., 6, 554-571, doi:10.2136/vzj2006.0093, 2007.

Velázquez, J. A., Schmid, J., Ricard, S., Muerth, M. J., Gauvin StDenis, B., Minville, M., Chaumont, D., Caya, D., Ludwig, R., and Turcotte, R.: An ensemble approach to assess hydrological models' contribution to uncertainties in the analysis of climate change impact on water resources, Hydrol. Earth Syst. Sci., 17, 565-578, doi:10.5194/hess-17-565-2013, 2013. 